\title{
IDENTIFICATION OF SYNTHETIC COLORS IN TRADITIONAL SNACKS AT GIANYAR SENGGOL MARKET
}

\author{
Ni Putu Eka Trisdayanti. \\ Sekolah Tinggi Pariwisata Nusa Dua Bali \\ eka.trisdayanti@yahoo.com
}

\begin{abstract}
The aim of this experiment is to identify synthetic colors in traditional snacks at Gianyar Senggol Market. As many as 12 samples brightly colored snacks (red, pink, green, yellow) have been analyzed. The method used is chemical analysis. The result is $100 \%$ of the samples examined do not contain synthetic colors, so it is safe for the public and tourists. It can provide additional value and media promotion to the public and tourists, that traditional snacks sold in the Gianyar Senggol Market not only tasty and having attractive appearance, but it also safe for health.
\end{abstract}

Keywords : synthetic colors, traditional snacks, market

\section{INTRODUCTION}

Tourism development in Bali can not be separated from the food as a tourist attraction. Moreover, ethnic food is a culinary destination favored by locals and tourists. Bali ethnic food produced using traditional methods gives effect not only on taste but also on food safety (Sujaya, 2013). Visually, factor of food colors seen at first sometimes also very crucial as to attract consumers. Natural dyes used in food have been known since long ago such as pandan leaves, leaf of suji and turmeric (Cahyadi, 2009). The food that was colored with natural dyes obtained from plants, animals or minerals has unstable dye by heat and light (Azizahwati, et al., 2007). However, natural dyes are generally safe and do not cause side effects on health.

As the development of science and technology, it has now found a synthetic color, which is more practical and cheaper. In Indonesia, the regulations regarding the use of permitted and prohibited coloring agents on food are regulated by decree of the Minister of Health No. 722 / Menkes / Per / IX / 88 on Food Additives. However, there is often a misuse of color, such as textile color is used to color food. Based on research conducted by Tresna Adhi in 2014 in Pasar Sindhu, Sanur, Bali, it was found that 2 out of 19 samples tested were positive for Rhodamine B. The Center for Food and Drug Administration (BBPOM) Denpasar in 2013, also conducted tests on food samples of schoolchildren snacks there was 1 sample containing Rhodamine B. BBPOM in Denpasar also performed testing on break fasting snacks and found as many as four samples using the banned dye Rhodamine B. Rhodamine B dye is usually used for paper, wool, and silk (Djarismawati, et al., 2004). Rhodamine B can cause irritation of the respiratory tract, skin irritation, eye irritation, irritation of the digestive tract, intoxication, impaired liver function and liver cancer (Wirasto, 2008). 
Province of Bali as a tourist destination, famous for its natural beauty and unique culture and distinctive culinary area is the main attraction for tourists both domestic and international (Adhi, Tresna 2014). Bali Culinary regional specialties that are included in the traditional snacks are found in many traditional markets, where sellers can freely and easily sell their products. Opportunities for food distribution containing hazardous materials in the traditional market are higher because of the difficulty of monitoring conducted by the market manager to oversee many merchants, especially the traditional snacks traders. Increasing number of the circulation of food containing hazardous materials can have an impact on the development of tourism in Bali.

Gianyar Senggol market is one of the traditional markets in Bali that is not only visited by locals but also tourists. To attract consumers, traders are likely to use synthetic dyes for coloring products. Therefore, it is important to identify synthetic colors in traditional snacks at Gianyar Senggol Market.

\section{METHOD}

The design used in this study was a descriptive qualitative, to identify the presence or absence of synthetic colors in traditional snacks. The sample in this study is the traditional snacks in red or pink, green, and yellow. The sampling method uses purposive sampling by taking samples of the food traders who sold traditional snacks that are red or pink green, and yellow. Analyzes of synthetic color was conducted in UPT-Analytical Laboratories Kampus Bukit Udayana University Jimbaran, Bali. Data analyzes technique used is descriptive qualitative. In this case the data is presented in table form and is grouped for easy identification, and then interpreted by the narrative.

\section{THEORITICAL REVIEW}

\section{Food Safety}

According to the Indonesian Government Regulation No. 28 of 2004, food security is a condition and effort needed to prevent food from possible contamination of biological, chemical and other substances that can disturb, damage, and harm human health. Food safety requirements are standard and other provisions that must be met to prevent food from possible danger, either because of biological, chemical or other substances that can disturb, damage, and harm human health. In order to provide a safe food adequately, it is necessary to create a food system that is able to provide protection for people who consume the food so that the food distributed and / or traded is not harmful and is safe for the health of the human soul. The use of food additives in the food production process needs to be watched together, both by producers and consumers. Irregularities in use would harm the young generation as a successor to the nation's development. In the field of food, it needs something better for the future, that food is safe for consumption, higher quality, nutritious, and better able to compete in global markets. Food safety policy (food safety) and the development of national nutrition (food nutrients) are an integral part of a national food policy, including the use of food additives (Cahyadi, 2009). 


\section{Food Additives and Classification}

Food additives are substances that are not normally used as food and are usually not the typical components of food, have or do not have any nutritional value, which is intentionally added to food for the purpose of technology in the manufacture, processing, preparation, treatment, packing, packaging, and storage (Cahyadi, 2009). The intended use of food additives is able to improve or maintain nutritional value and the quality of the power of savings, making food more easily to be served, and facilitate the preparation of foodstuffs. Food additives used can only be justified if it is intended to achieve each purpose of use in processing, are not used to conceal the use of inappropriate or that do not meet the requirements, not being used to conceal the workings contrary to the good way of the production for food, and not be used to hide the damage of foodstuffs (Cahyadi, 2009).

In general, food additives can be divided into two major categories, namely 1) food additives that are deliberately added to foods by knowing the composition of the material and in order to maintain the freshness, flavor, and help processing, for example preservatives, dyes, and hardener , 2) food additives are not intentionally added, a material that does not have a function in the food, it is there inadvertently, either a little or quite a lot because of mistreatment during production, processing, and packaging. This material can also be a residue or contaminants from the material intentionally added for the purpose of production of raw material or treatment that is still carried over into the food that will be consumed. Food additives example in this group is the residue of pesticides (including insecticides, herbicides, fungicides, and rodenticides), antibiotics, and Polycyclic aromatic hydrocarbons.

In Indonesia, regulations on permissible food additives added and prohibited (called Supplementary Chemical Material) by the Ministry of Health set up by the Ministry of Health of the Republic of Indonesia No. 772 / Menkes / Per / IX / 88 and No. 1168 / Menkes / PER / X / 1999 in Cahyadi (2009). Food additives groups that are allowed include:

1. An antioxidant, a compound that can slow oxidation in the material, such as ascorbyl stearate in food margarine, peanut oil, coconut oil and other oils

2. Anti Kempal, is anhydrous substance or substances which can absorb water without getting wet, eg, aluminum silicate on the type of foodstuffs milk powder and cream powder

3. Regulatory acidity (asidulan), a chemical that is acidic and can create pungent flavors and colors or creating after-taste that is not liked, for example, glacial acetic acid on processed cheese, canned sardines and other canned similar fish

4. Artificial sweeteners, according Winarno (1997) in Cahyadi (2009) is a substance that can cause taste sweet or sharpen the acceptance of the sweet taste, and the resulting calories are lower than sugar, for example sucrose, lactose, and sorbitol

5. Bleach and flour bund, the food additives to maintain the characteristics of white flour and to improve the quality during processing, for example, ascorbic acid and acetone peroxide

6. Emulsifiers, stabilizers, thickeners is a material that can reduce the speed of the surface tension and the tension between the two phases that under normal circumstances are not mutually dissolved into immiscible hereinafter form of 
an emulsion, for example agar, alginic acid, on the type of food ice cream sardines, and cheese

7. Preservatives, the material used to preserve food that has easily damaged properties to inhibit or to slow down the process of fermentation, pickling, or decomposition caused by microbes. Examples of food additives namely potassium nitrite, sodium nitrate, and sulfur dioxide on food sausages, canned corned beef, and cheese

8. Hardener, which can harden or prevent to be soft food. For examples, calcium gluconate and aluminum ammonium sulphate on food pickles in a jar, canned fruits, canned tomatoes and jellies.

9. Color, consisting of natural and synthetic dyes. Examples of natural dyes that are turmeric and leaves of suji whereas synthetic dyes include eritrosin, and tartrazine.

10. Flavoring, the sense amplifier food additives can provide, add or reinforce the flavor and aroma, as examples of essential oils and derivatives, oleoresins, spices, herbs, and leaves

Group of food additives that are banned from use in food include sodium tetrabonat (borax), formalin (formaldehyd), vegetable oil dibrominasi (brominanted vegetable oils), chloramphenicol (chlorampenicol), potassium chlorate (potassium chlorate), dietilpirokarbonat (diethylpyrocarbonate, DEPC), nitrofuranzon (nitrofuranzone), and salicylic acid and its salts (salicylic acid and its salts). There are also prohibited food additives namely Rhodamine B (red dye), methanyl yellow (yellow coloring), dulsin (artificial sweetener), and potassium bromate (hardener).

\section{Synthetic Colors and Health Impacts}

Synthetic dyes or artificial dyes are chemically made by the manufacturer or the chemical industry. Not all synthetic dyes can be used as food additives. Dyes are often misused in its use, such as textiles and leather dyes used for coloring foodstuffs. Price of dyes for textiles is much cheaper compared to the price of food dyes and the colors of textile or leather dye is much more attractive (Cahyadi, 2009). Therefore, the food processing staff do fraudulent acts in order to get a profit as much as possible.

Chronic effects caused by synthetic dye if it is eaten in a long time can cause liver cancer (Cahyadi, 2009). Rhodamine B is one of the synthetic dyes that are carcinogenic so that in the long-term use can cause cancer. Some of the results of toxicity tests showed Rhodamine B have LD50 more than $2000 \mathrm{mg} / \mathrm{kg}$, and can cause strong irritation of mucous membranes (Otterstätter, 1999, in Wirasto, 2008). In addition, the impact of eating Rhodamine B in large numbers and repeatedly dumps in the body that can cause irritation of the mucous gastrointestinal, and inhalation can irritate the respiratory tract, skin irritation, eye visible redness and edema (Yulianti, 2007), as well as cause damage to organs liver, kidney and spleen (Trestiati, 2003; Lee et al., 2005). As well as other synthetic dyes it also causes effects that are not good for health. Such as the excessive use of Ponceau SX can cause damage to the urinary system and can lead to tumor (Yulianti, 2007). 


\section{RESULT AND DISCUSSION}

Gianyar Senggol Market is one of the traditional market is located in Gianyar Indigenous Village, District Gianyar, Gianyar. Gianyar Senggol Market is located in the center of Gianyar, so that the access to the market is very easy to be able to reach this market from some cities in Bali can be reached by using public transportation such as Bus, Taxi and Trans Sarbagita routes serving Denpasar, Badung, Gianyar and Tabanan. Gianyar Senggol Market provides a variety of traditional foods such as babi guling, lawar, serombotan, ayam betutu, various Pepes, as well as a variety of traditional snacks such as klepon, pisang rai, bubur sumsum, etc. This market deserves to be one of the typical culinary tourist destinations Bali. Senggol market is opened from 2 pm until $12 \mathrm{pm}$.

Researchers took samples by using purposive sampling by taking samples of snacks in red, pink, green, and yellow. Researchers took 12 samples from 3 snack market traders to be tested in UPT-Analytical Laboratories Kampus Bukit Jimbaran, Bali. The test results of samples are as follows:

Table 1. Sample Laboratory Testing

\begin{tabular}{|l|l|c|c|}
\hline No & Sample Code & Color Origin & Result \\
\hline 1. & Bubur Sumsum & Green & Negative \\
\hline 2. & Pisang Rai & Green & Negative \\
\hline 3. & Dadar & Green & Negative \\
\hline 4. & Klepon & Green & Negative \\
\hline 5. & Giling-giling & Green & Negative \\
\hline 6. & Putu Mayang & Green & Negative \\
\hline 7. & Pisang rai 1 & Green & Negative \\
\hline 8. & Pisang rai 2 & Green & Negative \\
\hline 9. & Pisang rai 3 & Red/Pink & Negative \\
\hline 10. & Pisang rai 4 & Red/Pink & Negative \\
\hline 11. & Giling-giling & Red/Pink & Negative \\
\hline 12. & Kue Lumpur & Yellow & Negative \\
\hline
\end{tabular}

Based on lab tests, $100 \%$ of the samples examined do not contain synthetic dyes, so it is safe for consumption and does not cause side effects on health. The laboratory test results showed that the traders / snack makers do not use synthetic or artificial dyes in processed snacks. The snack processing uses natural dyes from nature. It can provide additional value and media promotion to the public and tourists, that traditional snacks sold at Gianyar Senggol market not only tasty and attractive in appearance, but also safe for health.

\section{CONCLUSION}

The conclusion from these results are that the samples of snacks sold at Gianyar Senggol Market were not found using synthesis color, so that it is safe for people or tourists to be consumed. 


\section{REFERENCES}

Adhi, Tresna \& Utami, Arya. (2014). Laporan Penelitian Analisis Kandungan Methanil Yellow Dan Rhodamin B Serta Persepsi Pedagang Terhadap Penggunaan BTP pada Minuman dan Jajanan Di Pasar Tradisional Desa Sanur Tahun 2014. Denpasar.

Azizahwati, Kurniadi \& M., Hidayat, H. (2007). Analisis Zat Warna Sintetik Terlarang Untuk Makanan Yang Berada Di Pasaran. Majalah Ilmu Kefarmasian, IV (1): 7-8.

Balai Besar Pengawas Obat dan Makanan di Denpasar. (2013). Laporan Tahunan Balai Besar Pengawas Obat dan Makanan di Denpasar Tahun 2013. Denpasar.

Cahyadi, W., \& Rachmatika, R. (eds), (2009). Analisis dan Aspek Kesehatan Bahan Tambahan Pangan. Bumi Aksara, Jakarta.

Djarismawati, et al. (2004). Pengetahuan dan Prilaku Pedagang Cabe Merah Giling dalam Penggunaan Rhodamin B di Pasar Tradisional di DKI Jakarta. Jurnal Ekologi Kesehatan, 3 (1): 7-12.

Haslina. (2004). Nilai Gizi, Daya Cerna Protein dan Daya Terima Patilo sebagai Makanan Jajanan yang di Perkaya dengan Hidrosilat Protein Ikan Mujair. Program Pasca Sarjana Magister Kesehatan Masyarakat. Universitas Diponegoro.

Lee TA, Sci BH, Counsel. (2005). The Food from hell: food colouring. The Internet Journal of Toxicology, 2 (2).

Nasution,AS. (2014). "Kandungan Zat Pewarna Sintetis pada Makanan dan Minuman Jajanan di SDN I-X Kelurahan Ciputat Kecamatan Ciputat Kota Tangerang Selatan Tahun 2014”. (skripsi). Jakarta: Universitas Islam Negeri Syarif Hidayatullah.

Peraturan Menteri Kesehatan RI No. 239/Menkes/Per/V/1985 tentang Zat Warna Tertentu Yang Dinyatakan Sebagai Bahan Berbahaya. Departemen Kesehatan RI. Jakarta.

Peraturan Menteri Kesehatan RI No. 722 tahun 1985 tentang Bahan Tambahan Makanan. Jakarta.

Peraturan Pemerintah RI Nomor 28 tahun 2004 tentang Keamanan, Mutu, dan Gizi Pangan. Jakarta.

Permatasari, et al. (2014). Identifikasi Zat Pewarna Rhodamin B dalam Jajanan yang Dipasarkan di Pasar Tradisional Kota Bandar Lampung. 24-33.

Sujaya, I N. 2013. Kualitas mikrobiologis pangan etnik Bali. (unpublised). 
Trestiati, Mela. (2003). Analisis Rhodamin B pada Makanan dan Minuman Jajanan Anak SD (Studi Kasus : Sekolah Dasar di Kecamatan Margaasih Kabupaten Bandung). Tesis. Pascasarjana Fakultas Kesehatan Lingkungan. Bandung.

Wirasto. (2008). Analisis Rhodamin B dan Methanil Yellow dalam Kecamatan Laweyan Kotamadya Surakarta dengan Metode Kromatografi Lapis Tipis. Fakultas Farmasi Universitas Muhammadiyah, Surakarta.

Yulianti, Nurheti. (2007). Awas ! Bahaya Dibalik lezatnya Makanan. CV. ANDI offset, Yogyakarta: 92-93. 